\title{
THE LECOMPTON CONSTITUTION
}

\author{
By L. Ethan Ellis
}

For two generations the Lecompton Constitution has lain hidden from the public eye in a Rutgers safe. Recently Dr. Ellis has sought out the history of this famous document, and he here tells its story. Dr. Ellis is the author of A History of the Chicago Delegation in Congress, 18431925 and of many articles in professional magazines. His most recent book is Reciprocity 1911: A Study in Canadian-American Relations, published by the Yale University Press for the Carnegie Endowment for International Peace.

$K_{\text {ANSAS }}$ in the eighteen-fifties was a chessboard on which were made K many of the important moves leading to the Civil War. Opened by the ill-starred Kansas-Nebraska Act of 1854 to the operation of the principle of Popular Sovereignty, the territory attracted aggressive supporters and opponents of slavery. ${ }^{1}$ The Emigrant Aid Society, motivated by an anti-slavery urge combined with a canny New England desire to make money on land speculation, sent settlers, and its members sent Sharps rifles in boxes labelled "books."' Southerners came in smaller numbers despite repeated urgings. ${ }^{3}$ This lack of numbers was for a time compensated by the convenient proximity of slave-owning Missourians, honestly fearful of the establishment of a free state on their borders, which would leave their twenty-five million dollars' worth of slave property surrounded on three sides by free territory. ${ }^{4}$ These honest patriots (or Border Ruffians) flocked promptly into Kansas during the controversy's early stages and cast any number of ballots requisite to turn elections for the pro-slavery party.

The first two of these elections, one for a territorial delegate to Congress and the other for a legislature, were carried for slavery by combi-

1 General narrative accounts of the Kansas troubles will be found in McMaster, J. B., A History of the People of the United States from the Revolution to the Civil War (8 vol., New York, 1883ff.), vol. 8; Rhodes, J. F., History of the United States from the Compromise of 1850 to the McKinley-Bryan Campaign of 1896 (8 vol., New York, 1893ff.), vol. 2; and Spring, L. W., Kansas: The Prelude to the War for the Union, Boston, 1885.

2 Johnson, S. A., "The Emigrant Aid Company in Kansas," Kansas Historical Quarterly, 1, 429-441.

${ }^{3}$ Lynch, W. O., "Popular Sovereignty and the Colonization of Kansas," The Mississippi Valley Historical Review, Extra Number, May, 1919, 380-392.

"Klem, Mary J., "Missouri in the Kansas Struggle." Ibid., 393-413. 
nation of Missouri intervention and free-soil indifference. By 1855, however, the free-soilers began to organize and in October met and framed the Topeka Constitution, ratified in December at an election from which the advocates of slavery held aloof. The Constitution was presented to Congress in March, 1856, with the request that Kansas be admitted under it as a free state. This year saw increasing friction in Congress and country over the Kansas issue. Senator Charles Sumner's "Crime Against Kansas" speech in May, followed by the brutal assault upon him by Preston Brooks, high-lighted a bitter and lengthy congressional debate. In Kansas itself the preceding lack of friction was dissipated into acts of violence on both sides which attained the level of a local war. Against this background a free-soil legislature, elected in January, 1856, met at Topeka in July. In October another pro-slavery legislature was elected; again the free-soilers absented themselves. This body designated June 15,1857 , for the election of delegates to a constitutional convention. Again the free-soilers stayed at home and a minority of the voters chose the delegates.

These facts form the setting of the convention which, meeting at Lecompton from September 7 to 11, adjourned until October 19 and completed its work on November 7. It was through the medium of the constitution here drafted that the pro-slavery elements sought first to commit Kansas to slavery, and then to secure the erection of Kansas into a slave state without giving the people of the territory a true opportunity to vote on the merits of that institution.

The engrossed draft of the Lecompton Constitution is now in the custody of the Rutgers University Library. It will be the object of the ensuing paragraphs to piece together, from such material as is available, first, some brief account of events in the convention itself, and second, the way in which the document came to the Library.

Events were demonstrating, during the course of 1857, that the antislavery cause was on the make in Kansas. Since a territorial legislature was scheduled to be elected in October, the Lecompton Convention remained in session but five days in September-long enough to organize and place in the presiding officer's chair John Calhoun, Surveyor General of Kansas and Nebraska, a Bostonian born, who settled in Illinois, where he had helped Abraham Lincoln to learn surveying. Calhoun had become a Douglas Democrat, and through this connection secured his posi- 
tion in Kansas. ${ }^{5}$ Organization accomplished, the convention took an adjournment to await the results of the October election. When the returns indicated a free-soil legislature, it became apparent that the convention might provide the last opportunity for establishing slavery in Kansas. Under these circumstances procedural methods become of major significance in the development of events. ${ }^{6}$ The first step bearing upon the present story was taken in the adoption, October 30 , of the following preamble to the report of the Committee on Slavery: "The right of property is before and higher than any Constitutional sanction, and the right of the owner of a slave to such slave and its increase is the same, and as inviolable as the right of the owner to any property whatever." A later provision prevented the amendment of the new Constitution prior to 1864 and by holding that in such amendment "no alteration shall be made to affect the rights of property in the ownership of slaves," attempted to fasten slavery permanently upon Kansas.

There remained one more problem - how to secure the Constitution's ratification with this slavery-guarantee, in the face of the undoubted free-soil popular majority? The evidence available to the writer is insufficient to speak with finality upon the sequence of events. The crucial pages of the convention's Journal are missing from the printed record and the principal account accessible is obviously inaccurate in details and subject to the bias of political partisanship. It is found in the testimony before the Covode Committee, in May of 1860, of Henry L. Martin, a clerk in the Interior Department, who went to Kansas at the behest of Secretary Jacob Thompson-officially to transact business connected with the Land Office at Lecompton; actually to do what he could to influence the course of events in the convention. With these reservations, the story as Martin recounted it is as follows. ${ }^{7}$

The pro-slavery convention divided sharply on the question of whether or not its work should be submitted to the risk of a popular vote in an area now obviously free-soil. The conservative wing, realizing the likelihood of defeat, still advocated submission. This was because they feared that if a pro-slavery Constitution were presented to

- Dictionary of American Biography (21 vol., New York, 1928-1937), 3, 410-411.

- House Report 377, 35th Cong., 1st Sess., 23-73, contains the Journal of the convention through November 3, but lacks the account of the crucial events to be described below. The Constitution itself is printed in Ibid., 73-92. Quotations in this sketch are taken direct from the document.

7 House Report 648, 36th Cong., 1st Sess., 93-325, contains much Lecompton material. 
Congress without a referendum, that body would reject it; they feared that the Southern states would consider this an attack upon slavery and would make it the signal for disunion moves. Accordingly, Martin worked with Calhoun and other leaders, in caucuses and on the floor, in favor of submission. The matter was taken up in a crucial report of the Committee on Schedule, headed by Hugh M. Moore and mainly favorable to submission. The majority reported in favor of submission but Blake Little in a minority report proposed sending the completed Constitution direct to Congress with a request for statehood. Bitter argument and complicated parliamentary juggling produced the plan finally adopted.

This well-known device (contained in Section 7 of the Schedule) called for an election December 21, 1857, at which the ballots should be marked "Constitution with slavery" and "Constitution with no slavery." If the second alternative triumphed, "then the article providing for slavery shall be stricken from this Constitution by the President of this Convention, and slavery shall no longer exist in the State of Kansas, except that the right of property in slaves now in this Territory shall, in no manner, be interfered with. ..." [writer's italics]. This gave the voters a chance to restrict the future advance of slavery in Kansas, but it effectively remanded the two or three hundred slaves already in the territory, and their descendants, to perpetual servitude; furthermore, it forestalled the intention of the free-soilers to defeat the Constitution at the ballot-box by offering them the Constitution, with or without slavery-a document which perpetuated the existing slavery in Kansas. This compromise proposal passed the convention by a majority of three. The election was held in due course, the free-soilers stayed at home, and Calhoun duly announced a smashing victory for the Constitution with slavery. By January 4, 1858, the free-soil legislature submitted the whole Constitution to a referendum in which it was roundly defeated. Before this last act, however, party strategy had dictated removal of the question to the national arena and Lecompton passes off the local stage even as pro-slavery influence was declining in Kansas.

The records available show that the written Constitution adopted at Lecompton came into the custody of the Rutgers University Library through presentation of the document to the New Brunswick Historical Club in the autumn of 1875 . The donor was Col. Alfred W. Jones, who had gone to Kansas in 1855 commanding a company of colonists from 
Petersburg, Virginia ${ }^{8}$ He later became editor of The Lecompton Union and National Democrat, and by his own testimony shortly receded from his extreme pro-Southern attitude, becoming what he himself defined as a "pro-slavery conservative." He was a delegate to the Lecompton Convention, representing Douglass County. The circumstances of his translation to New Jersey are not clear, but he appears with Henry Farmer as the editorial partner in the revival of the Middlesex County Democrat (Perth Amboy), issued first under date of May 23, 1868 ${ }^{9}$ In November of this year he was elected to the State Assembly from the Second District of Middlesex County, ${ }^{10}$ and in April, 1876, launched at Woodbridge, New Jersey, The Independent Hour, which continued under his auspices until the summer of $1879 .{ }^{11}$

No evidence which has come to hand indicates how he gained possession of the document under discussion. A letter in the Minute Book of the New Brunswick Historical Club, written from Woodbridge, October 29,1875 , accepts a previously-tendered invitation to address the organization. In it he presents to the Club "the original engrossed copy, enacting a State Constitution for Kansas Territory; being the widely known, veritable 'Lecompton Constitution.' . . " He goes on to request that if "the New Brunswick Historical Club, should ever become dissolved, or inoperative, for any cause, I ask the privilege of having this parchment filed in the archives of Rutgers College. . .."

The document itself is inscribed on eight sheets of parchment, each approximately twenty-three and one-half by twenty-seven and onefourth inches in size, the writing, now somewhat faded, but still sufficiently legible to indicate that the printed versions show only modifications of punctuation from the original draft. The concluding page bears the signatures of Calhoun (a delegate from Douglass County, as was Col. Jones), Charles H. Mcllvaine, Secretary, and of forty-four delegates representing fifteen counties. It constitutes an interesting memento of some historical importance, commemorating one of the tactical moves in the contest of sectional maneuver which presently dissolved into the clash of arms.

${ }^{8}$ Craik, E. L., "Southern Interest in Territorial Kansas, 1854-1858," Collections of the Kansas State Historical Society, 1919-1922, vol. 15, 334-450; The New Brunswick Daily Fredonian, November 5, 1875.

MS Minute Books of the New Jersey Editorial Association, 1, 104.

${ }^{10}$ Daily Fredonian, November 4, 5, 7, 1868.

${ }^{11}$ New Brunswick Daily Times, April 17, 1876; Daily Fredonian, July 14, 1879. 